\title{
ARMED FORCES AND INTERVENTION IN TROPICAL AFRICA
}

Dr S.J. Baynham*

\section{Introduction}

\begin{abstract}
"The Ghana Armed Forces, in co-operation with the police, have thought it necessary to take over the reins of power and to dismiss the former President, Kwame Nkrumah, the Presidential Commission and all Ministers, and to suspend the Constitution and to dissolve Parliament.
\end{abstract}

This act has been necessitated by the political and economic situation in the country. The concentration of power in the hands of one man has led to the abuse of individual rights and liberty. Power has been exercised by the former President capriciously. The operation of the laws has been suspended to the advantage of his favourites and he has been running the country as his own personal property."

So ran part of the radio announcement from the Ghanaian military rebels following the successful coup d'état against Dr Kwame Nkrumah's Convention People's Party in the early hours of 24 February 1966 . And the accusatory themes have a by now all too familiar ring to them in the wake of dozens more interventions against civilian regimes in the two decades or so since Ghana's first coup. Certainly, early predictions about Black Africa's armies tended to minimise their potential role in the political sphere but the rash of military interventions in politics from about the mid-1960's has focused attention on the armed forces as major actors in the political environment. The rapid Africanisation of these armies following the departure of the metropolitan powers at independence; the weakness of the embryonic civilian institutions relative to the military establishments; the fact that army "professionalism" has (paradoxically) prompted rather than prevented military involvement in politics; and the susceptibility of the soldiers to the wider sources of factional conflict pervading African society - in particular to primordial cleavages all help to explain the penetration of politics into the barracks and the emergence of modern-day praetorian states where the military exercises independent political power.
In 1962, Evelyn Waugh wrote in the preface to Black Mischief: "Thirty years ago it seemed an anachronism that any part of Africa should be independent of European administration. History has not followed what then seemed its natural course". ${ }^{2}$ Similarly in the early 1960 's, many writers who were observing the emergence of new African states from colonial crysalis considered that the armed forces were unlikely to play a significant role in the political affairs of Tropical Africa ${ }^{3}$ However, the postcolonial rush of coups "has belatedly focused attention on the military as consequential and hitherto largely overlooked actors in the unfolding political drama ... by mid-1970 there had been more than 30 coups or abrupt changes of government in which the army played a major role". ${ }^{4}$

By 1975 , of the 42 member states of the OAU, 28 were under some form of military or civil-military government. ${ }^{5}$ Today, approximately half of the continent's 50 or so states are presently under military rule. In political complexion and orientation, these administrations range from the proWest and conservative government of Mobutu's Zairre and the new rulers in Guinea, through the mildly socialist examples of Liberia and Burundi to the Marxist and pro-Soviet regimes of Mengistu's Ethiopia and Kerekou's Benin. Most of the coups d'état from the men in uniform have been against civilian politicians but an increasing proportion are staged from within the military, by one set of khaki-clad soldiers against another. ${ }^{6}$

In retrospect, it seems surprising that the potential political significance of the military was not more fully anticipated. The small size of Africa's armies led scholars to minimise the threat from the military but military coups have usually involved only a few hundred troops. In Ghana, the National Liberation Council came to power in February 1966 when 500 soldiers, from an army of 10000 , toppled the regime of Dr Nkrumah; in the Congo (now the Republic of Zaïre), Mobutu "neutralised" the conflict between Lumumba and Kasavubu by taking Leopoldville (now Kinshasa) with 200 men in September 1960; and General Soglo of Dahomey (now Benin) was removed from power by 60 paratroopers in December 1967. 
At the time of Black African independence, when there was a precipitous shift of sovereignty from governments in London, Paris, and Brussels to inexperienced African regimes, the embryonic armies inherited a spirit and tradition of political impartiality. They were essentially non-political and non-conspiratorial. Today the opposite holds true: military intervention in politics, direct or indirect, overt and covert, has become endemic. The soldiers are a political force because of what they have done, and because of what everyone now realises they might do. How can we explain this dramatic metamorphosis?

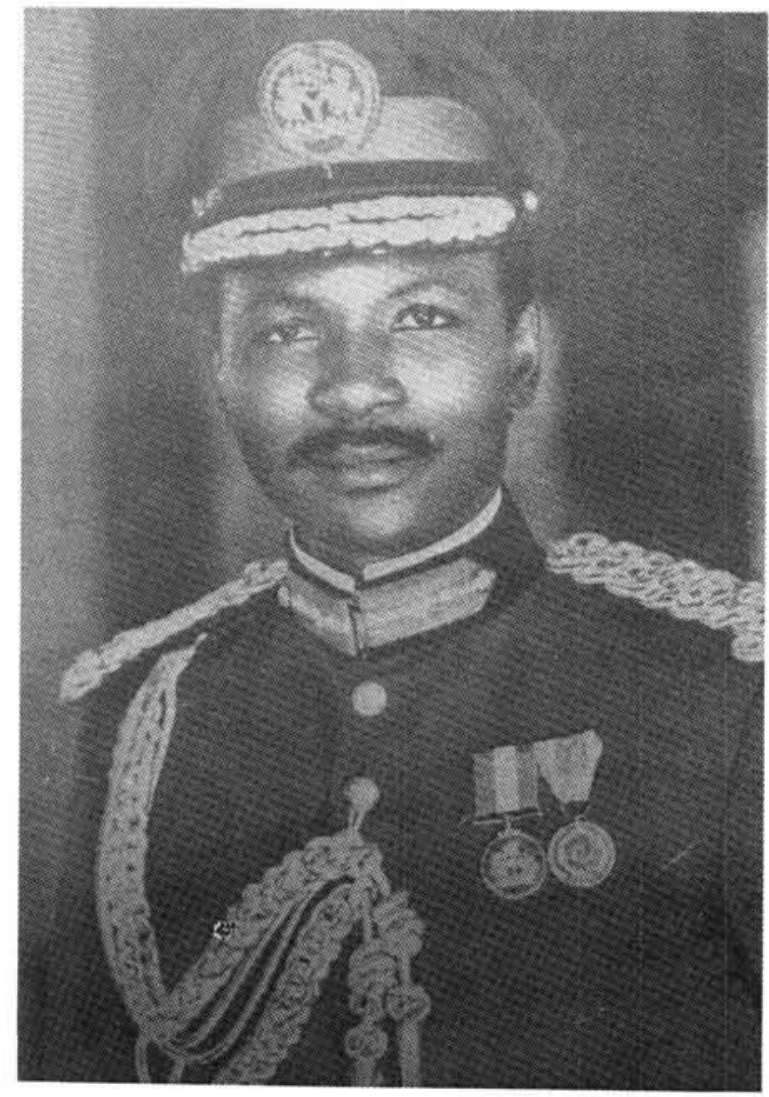

Major-General Yakubu Gowon, Commander-in-Chief of the Armed Forces and Head of the Federal Military Government

\section{Military Indigenisation and Professionalism}

Prior to the departure of the colonial powers at independence, many European and African officers expected to serve the new regimes as they had the old; and after independence most of the African armies continued to be heavily dependent upon expatriate officers for some years. Western doctrines of civilian supremacy and a non-political army, learned by example and precept, were accepted by the African officers and it was generally considered, as noted earlier, that the soldiers would not launch themselves into the political arena.

However, the progressive and often rapid indigenisation of the officer corps - the result of political as opposed to military imperatives had a disastrous effect on the internal stability of these armies. At independence in Ghana, for example, the army consisted of three battalions under a British officer corps, with some 30 Ghanaians in the lower ranks. Ghanaianisation of the officer corps was completed four years later in 1961. The Nigerian army was fully Africanised by 1965 - only seven years earlier, there were 45 African commissioned officers and six times as many British officers.

When the officers of the former metropolitan powers departed there was an immediate erosion of professional skills and serious deficiencies in military experience and organisational cohesion. ${ }^{7}$ Promotions took place at practically all levels of the officer corps, and although the majority of African officers were competent many of them lacked the experience and training for their new positions. In addition, the rapid elevation of inexperienced officers to higher posts generated unrealistic career aspirations, and expectations of such promotions remaining a permanent feature of the military career pattern were not borne out after the initial wave of promotions.

A situation was created in which a few years of seniority represented a wide gap in rank; this caused resentment and frustration on the part of second and subsequent generation officers who later faced promotional bottlenecks. The rapid Africanisation of the officer corps was a primary and potent source of institutional instability in the new African armies, although, as we shall see below, a variety of other factors have also contributed to the induction of the armed forces into positions of paramount importance in the political process.

We turn now to another key variable in any attempt to comprehend the military role, that is to the concept of professionalism. In The Soldier and the State, ${ }^{8}$ Huntington suggests the civilian supremacy over the military may be assured either by "subjective control", the permeation of the military by civilians values and interests; or by "objective control", in which the officer corps is disciplined by its own professionalism and corporate commitment to the military organisa- 
tion. "Professionalism" comprises, for Huntington, three ingredients. They are expertness, social responsibility, and corporate commitment to fellow-practitioners. Armies are expert technicians in the management and organisation of violence, they have a responsibility to the state, and they have a powerful corporate tradition and organisation. Huntington further argues that as the officer becomes more immersed in his technical tasks, the more he will leave politics to the politicians. As the military becomes more professional, it will become more "politically sterile. . . A highly professional officer corps stands ready to carry out the wishes of any civilian group which secures legitimate authority within the state". ${ }^{9}$
However, the argument that an adequate professionalism secures civilian supremacy is based on shaky empirical foundations. Professor Finer has pointed to several areas of civil-military relations where professionalism makes the military less rather than more responsive to civilian control. ${ }^{10}$ Although we shall be confining the application of these factors to the armies of Africa, their relevance to the military establishments of Western armies might also be of interest to the reader.

Firstly, the military may see itself as a servant of the state rather than of the particular government of the day. The military may have its own vision

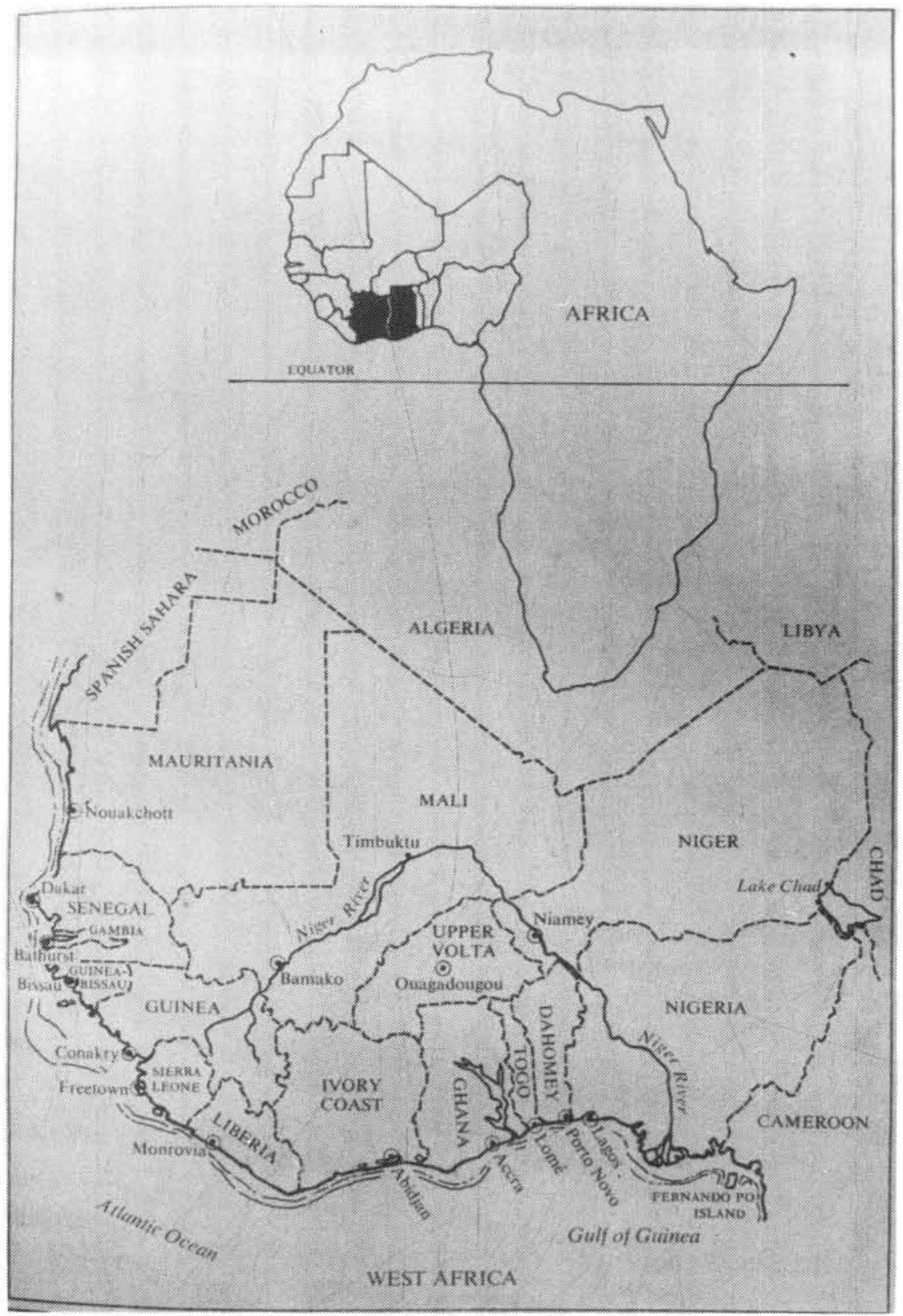

Map of inter alia Ghana and the Ivory Coast 
of the national interest and the officer corps, or a section of it, might regard it as their professional duty to protect the national interest (as it sees it) from an ineffective and corrupt administration. The post-coup speeches made by military coupistes invariably dwell on this factor. Following the 1966 army-police intervention in Ghana, MajorGeneral Ankrah claimed that the putsch had been motivated by the officers' patriotic duty to put an end to "mal-administration, mismanagement, the loss of individual freedom and economic chaos" inflicted upon Ghana by Nkrumah and his party apparatus. ${ }^{11}$ Ironically Nkrumah proved to be the spokesman of his own doom when, in a speech at the Ghana Military Academy in 1962, he said to the officers: "Loyalty demands of you that you place the interests of the State above all others." ${ }^{12}$ This is exactly what the soldiers claimed they did!

Secondly, "military syndicalism" might cause clashes of interest between the civil and military powers. As specialists in their field, the military hierarchy feel that they alone are competent to run the internal administration of the army. Harmonious civil-military relations require mutual respect for the limits of autonomy - of civilian authorities not to interfere in the professional concerns of the armed forces (command structures, systems of promotion, training methods, etc.) and of the armed forces not to interfere with the policy-making role of the civilian government. Political interference with the internal affairs of the army by Dr Busia's administration was a major factor contributing to military reintervention in Ghana by Colonel Acheampong in January 1972 . In addition, attempts by civilian governments to neutralise the army's technical monopoly of violence by building up counter-forces like the popular militia in Mali, for example, have been construed by the officers as "interference" with the politicians.

The third facet of civil-military relations where military professionalism may lead to less response to civilian control concerns the military's conception of its social function. Armies throughout the world, including African armies, are quite clearly reluctant to be used to coerce the government's domestic opponents. This is because the training of army officers usually predisposes them to regard external defence as their primary function despite the fact that there is likely to be a greater need for internal security duties than for external ones in many new African states. This outlook is tied up with the mili- tary's tendency to see itself as a servant of the state rather than of a particular government.

In Nigeria, the army's antagonism to the political class was increased by the use made of the army to provide a show of force for governmental authority, as in Tiv Division in 1960 and 1964 and the Western Region in 1965-6. General Christophe Soglo of Dahomey was deposed as Head of State in December 1967 after he tried to use many units to break workers' strikes. Major Kouandeté, who disliked the army being used to control industrial unrest, decided that instead of breaking the strikes he would use his units to depose Soglo. In Uganda, a large section of the officer corps resented Dr Obote's decision to use the armed forces to intimidate and subdue the Kabaka and his palace guard in May 1966.

In conclusion, it can be seen that mutually acceptable divisions of responsibility between the unclear domains of the civil and the military have not, for the most part, materialised and the politicisation of the officer corps has generally led to competition and conflict between the army and the politicians. The praetorian state has emerged in Africa partly because professionalism, rather than inhibiting military intervention in politics, has often promoted it.

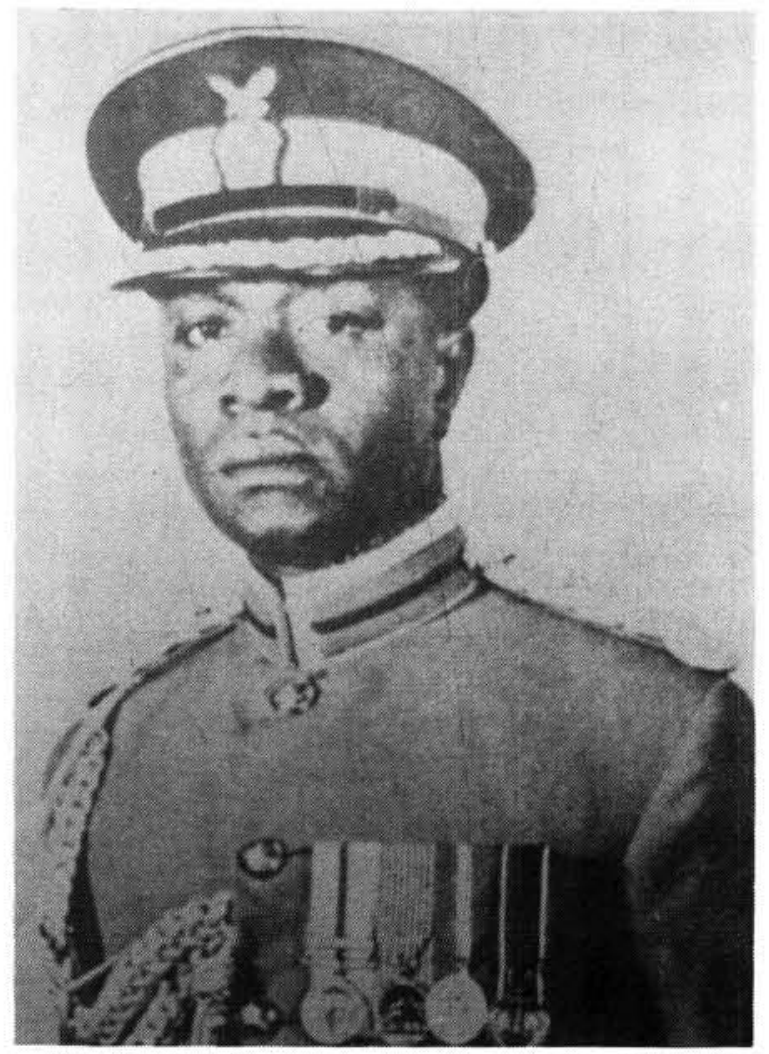

Colonel I.K. Acheampong, Chairman of the National Redemption Council 


\section{Primordialism and Other Sources of Intra- Military Factionalism}

Inter-tribal and inter-regional hostility abounds in Africa. Civil wars and abortive attempts at secession in Nigeria, Ethiopia, Zaïre, and the Sudan, as well as bloody conflict and ethnocide in Burundi and Equatorial Guinea, provide us with a few of the most memorable examples. The rule of the European metropolitan powers had ensured political cohesion but when independence came the forces of tribe and region were reasserted, political violence and conflict followed and in many countries the armed forces stepped in to "restore political order". How have primordial identities affected the political behaviour of African soldiers?

Despite the fact that military norms emphasise a national as opposed to a regional or tribal outlook, parochial attachments are not severed by military institutionalisation but they are considerably loosened. These ties begin to contract, however, when political events from the outside begin to permeate the military. Thus in Nigeria, during the period of civilian rule immediately prior to 1966, the political conflict, with its accusations and counter-accusations of "tribalism" aroused the interest of the army. Luckham has described in detail how this led to a situation where "army officers were casting apprehensive eyes at their colleagues", ${ }^{13}$ and the political situation acted as a catalyst to re-charge the primordialism of group identity within the army. The Nigerian army eventually became the military counterpart of the competing regional groups in the country's politics and finally went to war with itself. Congo-Brazzaville has also witnessed tribal conflict within the army between officers from the North, like the Kouyou, and those from the South, especially the Lari, which eventually led to military intervention in 1965. In Uganda, politics during Obote's first administration polarised along ethnic and communal lines (as well as ideological ones). This polarisation was reflected in the army, leading eventually to Amin's coup d'état on 24 January 1971. Finally, civil-military relations in Ghana have been consistently imbued with tensions of an ethnic nature - especially between the Ashanti and the Ewe - and they are clearly evident in the "revolutionary" regime of Rawlings' Privisional National Defence Council at the time of writing early in 1985.

It can be seen that tribalism does affect and influence the African armies (especially during periods of military rule as we shall note below). although we are faced with a dichotomy when we review and analyse the influence of primordialism on the armed forces. On the one hand, the military, more than any other African institution, is a bastion of anti-tribalist sentiment. Indeed, many military coups have been partially justified as being an attempt to eradicate ethnic divisiveness in the country. On the other hand, when tribal politics have penetrated the military it has often led to a more violent conflict than if the clash had been confined to the politicians. It may even lead to a temporary regression to earlier forms of tribal warfare. Thus the susceptibility of the officer corps to ethnic influences, and the identification of the officers with the demands and aspirations of ethnic and local elites, should be regarded as a major aspect of the military's involvement in politics.

Apart from communal and regional rifts, other sources of factional cleavage exist within the African military establishments. Firstly, there are tensions based upon generational differences which have caused resentment between different strata of officers. We have already noted that the accelerated promotions resulting from the rapid Africanisation of the officer corps following independence caused jealousy among second and subsequent generations of officers who had faced promotional blockages. Many of these younger officers have had better formal education than their seniors (who have come up through the ranks) and consider themselves to be better equipped to command. Tensions based upon level of training and time of recruitment have undermined the stability and cohesiveness of the armed forces.

Another consequence of the Africanisation programme touched on earlier has been competition between the large clusters of officers at lower echelons of the officer corps. Fierce rivalry at these levels is generated by the fact that only a few officers will fulfil their career aspirations and reach the senior ranks of the military hierarchy. Had recruitment of men into the officer corps been more carefully regulated, promotional bottlenecks, a breeding ground for discontent and conspiracy, would have been largely avoided. Inter-generational and intra-generational conflicts have been exacerbated when political postings - often resulting from ethnic considerations - interfere with normal promotion procedures. In addition, generational tensions are often sharpened and compounded by ideological differences Military supplantment of the civilian regime may be considered as the cataly- 
tic agent that accentuates the divisions in the army, further assailing its organisational discipline and cohesion. During periods of civilian rule political demands from the military establishment and other interest groups are directed towards the civilian politicians. But once the army assumes power, pressures from these groups are focused on the military. The acquisition of a new political role by the army exposes it to unaccustomed political demands and pressures. Once the army shifts its centre of gravity from the barracks to the seat of government it soaks up social schisms, making it an unreliable arbiter of political conflict. Personal rivalries and the intra-military tensions and cleavages described above are given fresh scope for development.

The further disintegration of the military establishment's cohesion during periods of military rule is characterised and promoted by conspiracies and counter-coups. The military seizure of power destroys the strongest unifying feature of the army, but once the taboo of the non-political army is shattered "the officers and the soldiers ... begin to identify not with their seniors, who have defied the rules and thus broken the obligation of military discipline, but with their equivalents in civilian life, their army generation, their political associates or their kinsmen". ${ }^{14}$

When this occurs, the politicisation of the military establishment is complete, and the soldiers find that they have become primary actors in the political process.

\section{Analysis of Military Intervention}

In this penultimate section, we will attempt to develop some general answers to the question: Why do soldiers intervene in politics? With reference to some of the vast literature on the subject, we shall ask what the armed forces intend to accomplish in overthrowing civilian governments. One approach, that favoured by Lefever, classifies military intrusion into the political sphere into four recurring demands reflecting

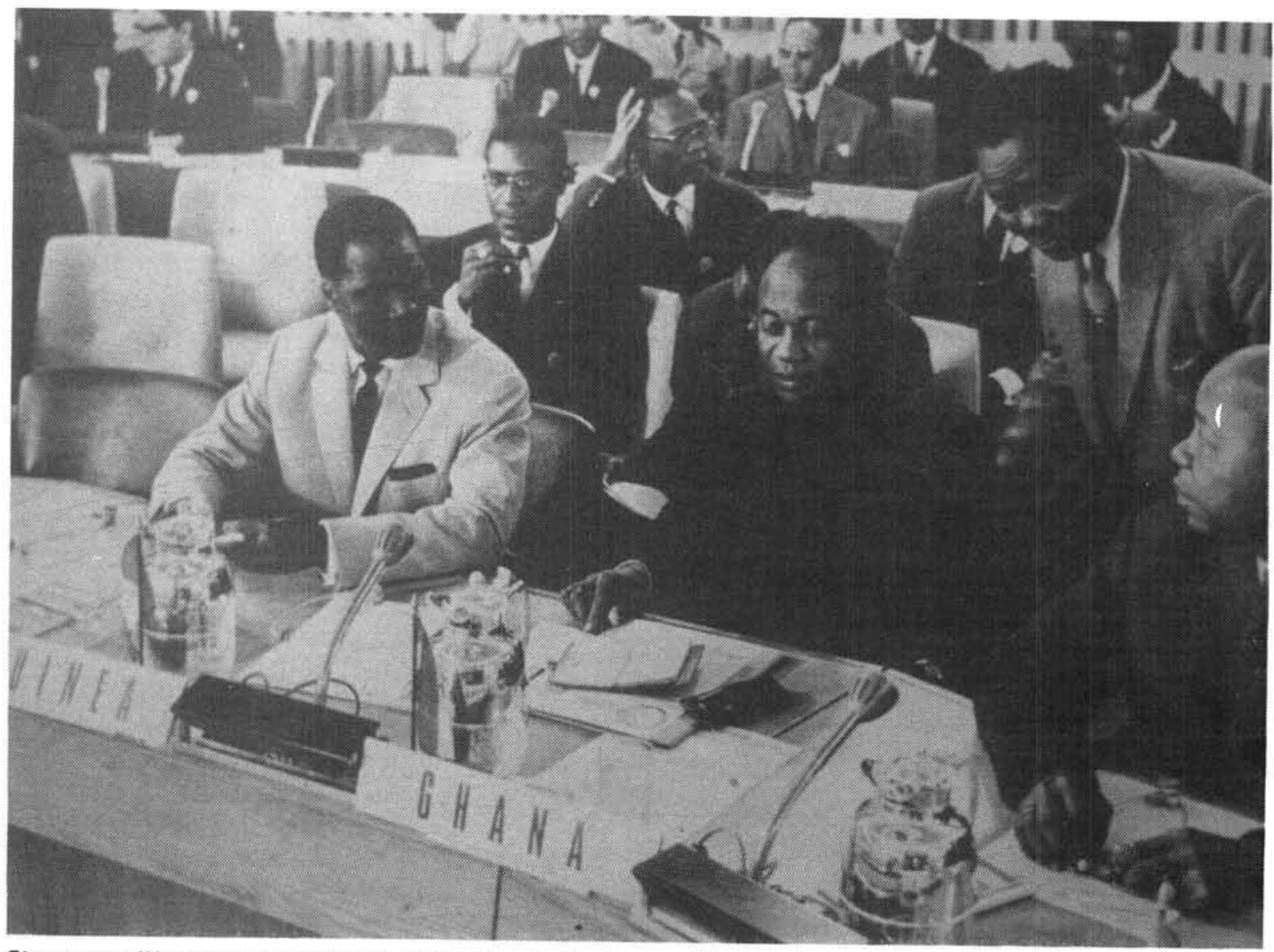

Strong-man West African presidents, Sékou Touré of Guinea and Kwame Nkrumah of Ghana, at a 1963 meeting in Adis Ababa establishing the Organization of African Unity 
the dominant motivation of the leaders of a particular coup. ${ }^{15}$ The "security" coup is undertaken to replace a regime judged incapable of defending the state from internal or external challenges. In such a situation, the primary aim of the coupmakers is to check the further disintegration of the state by restoring order and security and keeping the administration going until the political processes can return to a situation approximating normality. Mobutu's interventions in the Congo in September 1960 and October 1965, and the middle-ranking officers who led the January 1966 coup in Nigeria, were influenced by such considerations. Thus it was in these terms that the officers concerned attempted to legitimise their actions.

In the second place, military intervention may be prompted by a dissatisfaction with the character or policies, as opposed to the competence, of the regime. Such a coup has as its primary object the reform of domestic or foreign policy and can best be categorised as the "reform" coup. In this category, one of the best examples is provided by the 1966 coup (with which we began this article) in Ghana. The army and police officers were fundamentally affronted by the illiberal and corrupt character of the CPP regime. When the junta came to office, it insisted on new domestic and foreign policies in which a new multiparty constitution was established and Nkrumah's pro-East European bias was corrected in favour of the Western democracies. More recently, the 1983 New Year's Eve coup by senior Nigerian officers demonstrated a clear irritation with the gross corruption and maladministration of the Shagari regime.

The "new elite" coup, our third classification, is motivated primarily by ambitious men who use the army to gain power and the economic rewards and societal status associated with the occupancy of political office. Thus, stating their cause in terms of modernisation and reform, the coup provides the quick answer to the soldiers' social aspirations. This type of coup is frequently motivated by, and meshed with, ethnic/regional rivalries and hence invites a counter-coup. In Benin, for instance, the spate of coups and counter-coups seems until recently to have had little relevance to security or policy matters and the country has earned itself the unenviable reputation of being the most flourishing centre of praetorianism in Tropical Africa today. There is a link between individual self-interest and the corporate self-interest of the military since it is no- ticeable that in most of the states that have been subjected to intervention "the military budget and rewards and conditions of the armed forces are sharply increased. The military receive a kind of donative akin to that of the Roman Praetorian Guard."16 Concurring with this third category, Nordlinger argues "that by far the most common and salient interventionist motive involves the defense or enhancement of the military's corporate interests. ${ }^{17}$

This leads us to Lefever's fourth categorisation, the "punitive" coup, which is motivated by grievances in the military establishment against the regime which is accused of slighting the status and prestige of the armed forces. In this sense, the military assaults on all threee civilian administrations in Ghana (against Nkrumah in February 1966, against Busia in January 1972 and against Limann in 1981) have had a punitive dimension to them.

However, is should be stressed that a clear distinction between different types of coup is not always apparent. Indeed, when examining specific cases of armed intervention, one usually, if not always, finds it is the result of multiple motivation although in practice one or two of the elements noted above tend to predominate.

Lee, who analyses the character and behaviour of eighteen Tropical African armies against the backdrop of the British and French colonial legacy, considers that the characteristic coup d'état is an attempt by the soldiers to preserve a state apparatus from which they benefit so lavishly. ${ }^{18}$ And First has written that the army usually strikes at government "in defence of its immediate corporate interests... The heat of the political crisis in new states is generated largely by the struggle over spoils between competing layers of the power elite; and the officer corps has a strong stake in the contest, since it is itself an elite group". ${ }^{19}$

Other studies of military interventions have concentrated on probing for the role of the isolated common factor: stage of economic development; length of independence period; types of political organisation; size of army; proportion of the state's military expenditure as a percentage of gross domestic product; origins and social background of army officers, etc. However, empirical results have proved to be mainly negative or unreliable and quantitative studies of this nature have failed to shed much light on the role of the military in African politics. 
Studies of civil-military relations in Black Africa cover 'n great deal of similar ground because the experiences of these new states are similar. But to assume that "popular discontent" or "economic stagnation" or "political ineptitude and corruption" brought about the coups d'état does not do justice to the unique combinations of circumstances which exist. Examination of military coups will find similar causes, but the differences lie in the relative influence of interplaying causes. The key to the study of military interventions is to examine a series of factors, the salience of whose components differs from one coup to another. ${ }^{20}$

\section{Conclusion}

For the most part only a quarter of a century in age, the new states of Tropical Africa are seriously deficient in the disciplines, habits and institutions essential to modern economic and political development. One of the major reasons for this weakness is that the formal transfer of legal authority from the metropolitan powers to the fledgling African regimes was not accomplished by a transfer of effective power. In very few of the states presently under review has anything comparable to the political authority of the departed Europeans emerged. In addition, the Western traditions of the former colonial powers have been of little relevance to the African states. For the most part, the political institutions - although not the administrative bureaucracies - failed to take root. They withered away or else were adapted out of recognition by authoritarian single-party machines. Legitimate avenues of opposition were squeezed out of existence, frequently leaving the military as the only real source of opposition. Unquestioned subordination to civilian rule was increasingly replaced, and is still being replaced (often for the second or third time), by direct military intervention in politics.

The most significant background factors to this "emerging picture have been efforts to enhance military subordination to civilians following Africanisation of the officer corps; the perpetuation, if not the intensification, of tribal and regional rivalries; precipitous declines in the legitimacy and effectiveness of civilian governments; and a deteriorating economic situation. The centralı political symbols and institutions are weak and national cohesiveness is elusive. So long as this political immaturity continues to exist in Africa, so too will the praetorian state be maintained. In the final analysis, one is left with a dilemma that has confronted politicians, philosophers and military strategists from Plato to Pliny and from Machiavelli to Marx: Quis custodiet ipsos custodes? (Who will guard the guards themselves?)

Dr S.J. Baynham is attached to the Department of Political Studies of the University of Cape Town

\section{Notes}

1. B.B.C. Monitoring Service reproduced in A.H.M. Kirk-Greene, Stay By Your Radios (Leiden: Afrika-Studiecentrum, 1980), p 57.

2. E. Waugh, Black Mischief (Harmondsworth: Penguin, 1962), p 5.

3. See, for example, L.W. Pye, "Armies in the Process of Political Modernisation", in J.J. Johnson (ed). The Role of the Military in Underdeveloped Countries (Princeton, N.J.: Princeton University Press, 1962), p 69; and W.F. Gutteridge, Military Institutions and Power in New States (London: Pall Mall, 1964), pp 141-144.

4. E.W. Lefever, Spear and Scepter (Washington, D.C.: Brookings Institution, 1970) p 18

5. W.F. Gutteridge, Africa's Military Rulers - An Assessment (London: Institute of Conflict Studies, 1975), pp 1-2.

6. As in Benin (December 1965), Nigeria (July 1966) or Ghana (July 1978 and June 1979).

7. A classic example is provided by the Belgian Congo where, following independence in Jüly 1960 , most of the expatriate officers disappeared almost overnight and discipline in the army disintegrated entirely.

8. S.P. Huntington, The Soldier and the State: The Theory and Politics of Civil - Military Relations (Cambridge, Mass.: Harvard University Press,
1957).

9. Ibid. p 84

10. S.E. Finer, The Man on Horseback (London: Pall Mall, 1962), Chapter Four.

11. Kirk-Greene, op. cit. p 59.

12. Press release No. $46 / 62$. Embassay of Ghana, Washington, D.C. Quoted by Lefever, op. cit. p 53 .

13. A.R. Luckham, The Nigerian Military (London: Cambridge University Press, 1971), p 193

14. R. First, The Barrel of a Gun (London: Allen Lane, the Penguin Press, 1970), p 437.

15. Lefever, op. cit. pp $28-9$

16. Finer, op. cit. p 87.

17. E.A. Nordlinger, Soldiers in Politics: Military Coups and Governments (Englewood Clifts, N.J.: Prentice Hall, 1977), pp 63-64. For a fuller discussion, see Chapter 3, "The Coup D'État"

18. J.M. Lee, African Armies and Civil Order (New York: Praeger, 1969).

19. First, op. cit. p 429 .

20. For a more comprehensive historiographical analysis of coup causes, see D. Horowitz, Coup Theories and Officers' Motives (Princeton, N.J.: Princeton University Press, 1980) 